\title{
USING SUSTAINABLE LIVELIHOOD APPROACH TO ANALYZE THE IMPACT OF COVID-19 ON THE SOUTH AFRICAN RURAL AGRICULTURAL MARKETS
}

\begin{abstract}
The coronavirus pandemic (COVID-19) has disrupted the operation of many economic activities around the world. Informal economic activities including rural agricultural markets were mostly affected by the impact of COVID-19 as those in the rural areas they lost access to urban markets. This study researched the impact of COVID-19 on the South African rural agricultural markets, using the Sustainable Livelihood Approach (SLA) as a primary theory. The study relied on secondary data which was collected by a case study and analyzed using a textual analysis. The key findings revealed that rural agricultural markets have been recognized as the main contributing informal activity to the South African economy. It showed that the COVID-19 pandemic disrupted these economic activities as the government introduced strict lockdown regulations to maintain social distancing and avoid the spread of the pandemic. The South African government must, therefore, implement a regulatory framework that will formalize the operation of informal traders in rural agricultural markets.
\end{abstract}

Keywords: Agricultural traders, COVID-19, Informal Traders, Rural Agricultural Market, Sustainable Livelihood Approach.

\section{INTRODUCTION}

The impact of the coronavirus ${ }^{3}$ (COVID-19) pandemic has shown to be a threat to the socio-economic development of countries across the global world. This crisis has placed informal traders under a vulnerability context as far as economic and the labour market is concerned. There are already growing reports on the economic losses faced by workers engaging in certain occupations due to lack of access to markets, reduced demand and the loss of mobility of people and goods. The informality nature of the rural agricultural market in South Africa has invited a significant need to understand the extent to which this economic activity has been impacted by COVID-19. This is because of the related

\footnotetext{
${ }^{1}$ Mfaniseni Wiseman Mbatha, MA, Department of Development Studies, University of Zululand, KwaDlangezwa, 3886 South Africa; e-mail: mwisemanmbatha@gmail.com. ORCID: 0000-0002$8631-1234$

2 Daniel Nkosinathi Mlambo, PhD, Department of Public Management, Tshwane University of Technology, Pretoria, 0152 South Africa; e-mail: mlambo1@ymail.com (corresponding author). ORCID: 0000-0001-9898-1414.

${ }^{3}$ In this article, the word coronavirus will be used interchangeably with covid-19.
} 
assumptions that assumes that workers from the informal sector were likely to lose their jobs and face extreme poverty and food insecurity as the COVID-19 intensifies across large informal economies (Shaikh, 2020).

Kiaga (2020) is of the view that the rural agricultural market and other informal activities already experience loss of income, which will lead to migration of people between rural-urban areas and this may possibly spread the COVID-19 in rural areas. The COVID-19 pandemic is mostly expected to affect small-scale farmers, small food retailers, street vendors, domestic workers and small food processing units as they lose access to urban markets. These aforementioned informal activities, according to Shaikh (2020) make the most contribution to the economy in the region, however, they are excluded from the legal and contractual protections of formal workers. The majority of these informal traders are from disadvantaged communities, so if information about COVID-19 is floating on social media circles, they struggle to access it as a result of lack of technology. It is for this reason that they are lacking information about the virus, its seriousness, the myths around it and most importantly its prevention techniques.

It is for this reason that this current article seeks to analyse the impact of COVID-19 on the South African rural agricultural market by using Sustainable Livelihood Approach (SLA) as a primary theory. The SLA is used because it allows rural people to be involved in making their livelihoods with the aim of promoting economic, social and environmental development. The critical aspect of the findings, therefore, reveals that the capital assets (human, physical and social capital) have received a hard hit from the COVID-19 in South Africa. Their disruption has come because of the strict regulations of the lockdown, which was introduced by the government in early March 2020 as a way of maintaining social distance among people in order to avoid the spread of the virus.

\section{UNDERSTANDING THE CONTEXT OF RURAL AGRICULTURE MARKET IN SOUTH AFRICA}

Agriculture is recognised as the backbone of the economy in many developing countries and South Africa in particular as it serves as a major source of employment and Gross National Product (GDP). While the agricultural market is understood as a lucrative channel towards contributing to the sustainable livelihood of rural communities. This is because the agricultural market plays an important role in food distribution and improving rural economies as it forms the central market whereby agricultural products are sold (Mbatha, Nojiyeza and Mdiniso, 2021). These agricultural products include freshly processed crops, fish, dairy product and white and red meat (Marocchino 2009). The sad reality behind the South African rural agricultural market is that its trade is mostly associated with the informal economy, which is discussed in the subsequent section.

\subsection{The Concept of Informality in the Rural Agricultural Market}

The concept of informality is usually used in distinguishing labour market across the world of million economic sections which are operating and where the majority of workers are chasing their livelihoods in informality conditions (ILO, 2020). In this context, the concept of informality is employed to define the type of workers and activities based on their state of operation, which is outside the modern economy and outside of the legal and regulatory framework (see Loayza, 2019). It is very important to indicate that rural agricultural market is playing a measurable contribution to the informal economy in most 
developing countries. Rural Agricultural Market is associated with the concept of informality based on the reason that its nature of work is featured by unhealthy and unsafe working conditions, small workplaces, unproductivity, low level of skills, and poor access to information, technology, training and finance. According to Rogan (2018), workers in the rural agricultural market are not well recognised, protected or regulated under social protection and labour legislation. This is because the informality nature of rural agricultural market consists of families or private households who are not protected by any job security. This, as a result, indicates that the majority of workers in this livelihood strategy are selfemployed and usually acting as street vendors or traders. However, Rogan (2018) further depicts that these workers are not paying Value-Added Tax (VAT) or taxes and they are struggling to employ others since they are not registered. It is, however, well acknowledged that even though the rural agricultural market is mostly operating as an informal economy but it plays an important role in terms of serving a social purpose and regarded as the main source of income for rural people to make their living sustainable.

\subsection{Agricultural Retail Market in Rural Areas}

Rural agriculture market also involves the availability of retail market or location used by rural farmers, agricultural producers and customers as their gathering point for the purpose of trading (selling, buying and supplying) of goods. Marocchino (2009) points out that the high rate of informality in the rural agricultural market is causing a challenge on the working conditions of the labour force in the retail market. Tracey-White (2003) recognises the significance of having effective marketing infrastructure towards minimising post-harvest losses and to reduce health risks in the rural retail market. This is because the efficiency in agricultural retail market is expected to play a crucial role in food security, income generation and developing strong linkages with respect to the rural market. Reardon, Timmer and Berdegué (2004) bring forward as a suggestion that the planners of the rural market are expected to come up with proper ideas in designing market that addresses both economic and social need of rural people. In addition, it is also very important to come up with a rural market that will be easily managed, maintained and operated by rural farmers. The essentialness of effective market regulations in the rural agricultural sector is well recognised and needed. These regulations must enforce revenue collection activities and hygiene rules inside a market. It is assumed in the context of this study that the poorness of these regulations has negatively contributed to the sustainable livelihood of rural farmers and traders during the spread of coronavirus across the global world. It is for this reason that this particular study seeks to analyse the impact of COVID-19 on the South African rural agricultural market through the use of SLA.

\section{SUSTAINABLE LIVELIHOOD APPROACH AS A THEORY}

The impact of COVID-19 to the sustainable livelihood of people across the globe is a current burning issue of which it requires massive and robust investigation. The present study recognises rural spatiality as the most part of the world that is suffering from the consequence of the COVID-19 as far as making the effectiveness of their livelihood is concerned. The SLA is used as a primary theory to analyse the impact of COVID-19 on the rural agricultural market in South Africa. Therefore, this is a very relevant theory that provides a proper explanation and analysis of the situation of the rural agricultural market during the hard times of COVID-19. The strength of SLA in the context of this study is that 
it allows rural people to be involved in making their livelihoods with the aim of promoting economic, social and environmental development. Malemela \& Yingi (2016) argues that this theory can play an important role in planning activities of development and help to analyses the contribution of existing activities to the livelihood of rural people. Nevertheless, this approach was introduced with the intention to reduce the issues of poverty by promoting economic development activities.

Petersen, Michelle, \& Pedersen (2010); Malemela \& Yingi (2016) argue that SLA can be employed in studies that anticipate dealing with issues of poverty by establishing economic activities including rural agricultural market. It further contributes to integrating the resources and market places as a way of improving rural livelihood. The framework for SLA, according to Ferguson (2012) also aim at acknowledging the strengths, capital assets, livelihood activities and opportunities that belong to rural communities and determines factors that shape those livelihoods. As far as the issue of the COVID-19 pandemic is concerned, the SLA helped to comprehend the set of ideologies behind the trading of farmers and other agricultural traders towards maintaining their livelihood through the rural agricultural market during the hard times COVID-19 pandemic. The authors contextualised the rural agricultural market as an important livelihood strategy for rural people to make their livings during the incidence of COVID-19 pandemic.

\section{METHODS AND MATERIALS}

The case study has been used to collect secondary data that is related to the COVID-19 pandemic, rural agricultural market and SLA. The dependence of this study on the secondary data aimed at collecting important information that has been collected by others through the use of primary research methods. According to Ponsignon, Durrieu \& Bouzdine-Chameeva (2017), a case study is a crucial tool in collecting information from various sources such as the officially published papers, technical reports, and documentation of data collection methods and procedures. These online sources, in the context of this study, played an important role in providing accurate information (Baxter, \& Jack 2008) on the impact of COVID-19 in the rural agricultural market. This data collection instrument assisted the authors to employ qualitative data to explain the process and results of the phenomenon through the full reform and analysis of cases that are under investigation. These authors, therefore, adopted textual analysis as an instrument to analyse collected data. The textual analysis assisted the authors to critically analyse the relevant reviewed literature.

\section{RESULTS AND DISCUSSIONS}

The rural agricultural market is the most economic activity that is being undertaken by South African communities as a way to improve their livelihood. This stems from the point that rural people depend more on trading agricultural product and it is where they are able to make decisions regarding the sustainable livelihood of their respective families. The main analysis and discussion of this study results are based on the basic elements of the Sustainable Livelihood Framework, which includes vulnerability context, capital assets and availability of regulation to guide livelihood strategies. 


\subsection{Rural agricultural market on the vulnerability context caused by COVID-19}

The result depicts the COVID-19 pandemic as one of those vulnerability contexts faced by rural people who are involved in the agricultural market to pursue their livelihood. Fishers (2002) argue that vulnerable context in SLA is recognised where people are suffering from the various risk of external changes, which also results in negative impact as people attempt to improve their living. The impact of COVID-19 has shown to be a threat to rural agricultural market as it caused a disruption in the value chain and market for agriculture. This is because both the agricultural market and value chain are recognised as the most essential components that affect rural livelihood. In this point, Food and Agriculture Organization (2020) argue that COVID-19 has placed small farmers, agricultural traders and agribusinesses into a vulnerability context due to the introduction of movement restrictions and lockdown, which resulted to their inability to process their agricultural product and access the market. Pafumi (2020) recognise that the vulnerability context caused by COVID-19 results in the declining demand of the agricultural product and lower prices, which negatively leads to the loss of income and sensitive waste of food. This is due to the point that the majority of workers and traders are struggling to generate income as there are being compelled by the strict regulations of lockdown to stay at their respective households as a way of reducing the spread of COVID-19 (Human Sciences Research Council, 2020).

Maintaining social distancing by staying at home is a most contributing factor to the vulnerability contexts of the rural agricultural market, mostly affecting small farmers, agricultural traders, customers and agribusinesses as far as the spread of COVID-19 is concerned. Lazarte-Hoyle (2017) maintain that vulnerability context can possibly happen from human actions and some can happen at an individual level, which may be related to the health issues or social risk. The study results further indicates that small farmers, agricultural traders and agribusinesses have complied with the regulations of coronavirus during the earlier stages of lockdown (level five and four) as they were scared to be infected by the spread of COVID-19. This adverse events as argued by Food and Agriculture Organization (2002) has frustrated rural people as they have suffered from hunger and food insecurity.

\subsection{Impact of COVID-19 on the Capital assets for Rural Agriculture Market}

The capital assets of SLA are recognised as pillars at which livelihood for rural people can be built. In the context of this study, these assets are assumed to play a crucial role in terms of uplifting situation of people who engage in rural agricultural market by reacting to the impact of COVID-19 as they attempt to adjust and overcome it. The results, therefore, show that COVID-19 has a negative impact on rural agricultural market in respect of human, financial, physical and social capital assets.

\subsubsection{COVID-19 on Human capital for the rural agricultural market}

The results reveal that human capital is the most aspect of SLA to experience a severe impact of COVID-19 as the small farmers and agricultural traders struggled to access agricultural market. According to Mapiye (2016) \& Serrat (2017), the human capital asset of SLA involves the obtainability of experiences, creativity, skills, labour and good health amongst people in rural areas. These aforementioned factors play an integral part to small farmers and agricultural traders to obtain desired livelihood outcomes from the rural agricultural market, which is their main livelihood strategies. It is, however, noted by the 
African Union (2020) that the introduced measures as a way to contain the spread of COVID-19 have forced small farmers and agricultural traders to close their daily operation and harshly reduced their involvement economic activities. This is assumed to be resulting in a long term recession in rural agricultural market as far as the continuing spread of COVID-19 is concerned. Blanke (2020) raises a concern about the health care system in Africa, which is assumed to be very weak as there is a spread of the pandemic. In addition, the spread of the COVID-19 puts at high-risk lives and livelihoods of rural communities and economic growth.

It is very important to note that in most African communities, there is an existence of informal economy including rural agricultural market which forms the backbone of the economy and provides most employment. Conversely, the impact of COVID-19 through lockdown has resulted to the human capital being disturbed as farmers and traders were not allowed to travel locally and internationally, hence, this risk pushed many local people into poverty, while others lost their jobs in the rural agricultural market. It is argued that if previous crises are any guide, the loss of employment and income is likely to have a serious and widespread impact on access to food from the retail market as they reduce the ability of vulnerable groups to purchase sufficient calories, let alone nutritious food (Blanke 2020). This is not solely an urban issue. Rural areas that depend heavily on purchased foodstuffs are also affected. The huge impact of COVID-19 on the human capital asset of SLA can be referred to the high probability that rural agricultural market in most part of the country will be suspended, downsize, or face bankruptcy as they are starved of capital. In this point, the British Broadcasting Corporation (2020) report that women and youth are the likely component of a human capital asset to be hit badly by COVID-19 in the rural agricultural market.

\subsubsection{COVID-19 on physical capital for the rural agricultural market}

The physical capital asset of SLA involves the availability of basic infrastructure that can be used by farmers and agricultural traders to attain their livelihood outcome through the rural agricultural market (Serrat, 2017). The results show that communication and transport to access rural agricultural market are the most components of a physical capital asset to be impacted by COVID-19. It can be argued that physical asset can assist small farmers and agricultural traders in transporting their agricultural produce to the market for commercial intentions (Chitongo, 2017). The results depict that accessing the retail market during the initial phase of lockdown has been difficult for farmers and agricultural traders since the operation of public transport remained shut down. The shutdown of public transport was mainly on the basis to maintain social distancing in order to slow down the spread of COVID-19 by limiting contact between people. This has negatively contributed to the rural agricultural market as the farmers and agricultural traders were not able to transport their product to the retail market. Mbonambi (2020) argues that other farmers and informal agricultural traders were unable to travel for the purpose of accessing permit to work during the high restricted time of lockdown. In addition, this has left people who are involved in informal agricultural activities with no more means to travel to offices to acquire such permit and polices still harassed those who got permits (Mbonambi, 2020).

\subsubsection{COVID-19 on social capital for the rural agricultural market}

The social capital asset of SLA encompasses the quality and quantity of social resource that can help farmers and agricultural traders to effectively attain their livelihood outcomes 
through the rural agricultural market. These social resources according to Serrat (2008) consist of cooperation of members, social relations and also access to the institutions that promote development in rural societies toward making a sustainable livelihood. It is, however, noted that the impact of COVID-19 has destroyed those social resources as people are forced by lockdown regulations to socially maintain distance as a way of avoiding the spread of the pandemic. The results further show that the social capital asset of SLA received a hard hit from COVID-19 as people in the rural agricultural market are struggling to adjust on the use of technology. Trendov, Varas, \& Zeng (2019) are of the view that technologies and digital innovations may play an important role in advancing several sectors and agricultural sector in particular. It is, therefore, assumed that the introduction of the Fourth Industrial Revolution has resulted in the rapid transformation of several sectors by disruptive digital technologies (FAO, 2017). United States Agency for International Development (2018) reports that in the agricultural sector, the spread of remote-sensing services, distributed computing and mobile technology are already contributing on the enhancement of informal traders and smallholders access to market, information, training and finance.

However, this has been an issue in South African rural agricultural market as the majority of farmers and informal traders were not prepared to opt for the use of technology since COVID-19 has disrupted their operation from the retail market. From the social perspective of SLA, African Union (2020) shares a view that the existing fragility in the economy could increase global unemployment since COVID-19 has disrupted the level of shared norms and trust that exist among farmers and agricultural traders in the rural agricultural sector. This is because their mission to overcome risks, accessing services, and acquiring information about improving their livelihood outcomes has been in jeopardy as far as the negative impact of COVID-19 is concerned

\subsection{COVID19 on regulations for Rural Agricultural Market}

The regulatory behind the rural agricultural market involves the availability of policies and institutions which can play an important role to improve the livelihood strategies of rural communities by transforming the capital assets. The findings of Ncube (2017) shows that there is the availability of government institutions (including Local Municipalities and the Department of Agriculture) that intendeds to bring support to the rural agricultural sector and informal traders. It is, however, noted that they lack regulatory framework or policies available to guide and protect the operation of rural agricultural market and other activities, which are recognised as contributors to the informal economy. The lack of regulation for informal traders has compromised their ability to trade during COVID-19 because of the strict regulation of lockdown. Christensen (2020) is of the view that the impact of COVID-19 has highlighted the existence of in equitability and negative perception in a way the South African government treats the informal sector, which actually plays a key role in the overall economy. Unlike in the formal sector, Shaikh (2020) has a perception that the continuing crisis of COVID-19 brings workers who engage in the rural agricultural market in an exceptional vulnerability of the economic and labour market shocks of the pandemic. This is due to the point that the majority of people in this sector are not protected by any regulations and they are continuously losing their jobs and facing extreme poverty as the COVID-19 intensifies across large informal economies. Kiaga (2020) maintain that the concern of government over the informal economy originates from the point that people who work in this sector have shown to be more vulnerable to impoverishment, hunger and 
disease, as they lack the necessary social protection coverage and support mechanisms if they lose their livelihood during these periods of COVID-19. Christensen (2020) bring forward as a suggestion that during the COVID-19 and after, it will be important to support the most vulnerable in society by ensuring that the informal safety net remains strong in a social and business prerogative.

\section{CONCLUSION AND RECOMMENDATIONS}

The paper analysed the impact of COVID-19 on the South African rural agricultural market by using SLA as a primary theory. The results of the study show that rural agricultural market is one of the activities which are mostly contributing to the informal economy. Therefore, the impact of COVID-19 has threatened this economic sector by disrupting the value chain and market for agriculture. The human capital asset has suffered the most since small farmers, agricultural traders and agribusinesses were struggling to trade due to the movement restrictions and lockdown as a way of containing the spread of COVID-19. The physical capital asset has been disrupted by a lockdown regulation of maintaining social distancing in order to limit contact between people. Thus, farmers and informal traders struggled as they were not able to transport their product to the retail market. The lack of technological advancement in the rural agricultural sector has been identified as farmers and informal traders were not prepared to opt for the use of technology since COVID-19 has disrupted their operation from the retail market. The results also reveal the existence of in equitability and negative perception in a way the South African government treats the informal sector which actually plays a key role in the overall economy since there is a lack of regulations that supports informal traders. It is, therefore, very important for the South African government to implement a regulatory framework that will guide the rural agricultural market. This regulatory framework will assist in formalising the rural agricultural market toward protecting the right of its labour force and daily operation activities.

\section{REFERENCES}

African Union (2020). Impact of the Coronavirus Covid-19 on the African Economy. African Union.

Baxter, P., Jack, S. (2008). Qualitative case study methodology: Study design and implementation for novice researchers. "The qualitative report", 13(4).

Blanke, J. (2020). Economic impact of COVID-19: Protecting Africa's food systems from farm to fork. Brookings. [Access: 19 July 2020]. Access on the internet: https://www. brookings.edu/blog/africa-in-focus/2020/06/19/economic-impact-of-covid-19-protectingafricas-food-systems-from-farm-to-fork/

Chitongo, L. (2017). The efficacy of smallholder tobacco farmers on rural development in Zimbabwe. Doctoral dissertation. University of the Free State [Access: 18.07.2020]. Access on the internet: https://scholar.ufs.ac.za/handle/11660/7602

Christensen, L. (2020). Covid-19 stimulus plan won't protect informal economy. Mail \& Guardian Online [Access: 20.07.2020]. Access on the internet: https://mg.co.za/ article/2020-04-24-covid19-stimulus-informal-economy/

FAO (2017). Information and Communication Technology (ICT) in Agriculture: A Report to the G20 Agricultural Deputies. Rome: FAO. 
Ferguson, J.A. (2012). Generating sustainable livelihoods; the role of cooperatives. Canadian cooperative association, paper presented at the Harnessing the Cooperative Advantage to Build a Better World, Ottawa.

Fisher, S. (2002). A livelihood less ordinary: applying the sustainable livelihoods approach in the Australian Indigenous context. Alice Springs, Australia: Centre for Appropriate Technology Inc.

Food \& Agriculture Organization (2002). Reducing Poverty and Hunger: The Critical Role of Financing for Food, Agriculture and Rural Development. International Conference on Financing for Development. Rome [Access: 20.07.2020]. Access on the internet: http://www.fao.org/3/y6265e/y6265e.pdf

- (2020). Decent Rural Employment: Impact of COVID-19 on rural youth employment. The Food and Agriculture Organization of the United Nation: Regional Office for Africa [Access: 18.07.2020]. Access on the internet: http://www.fao.org/rural-employment/ resources/detail/en/c/1276700/

Human Sciences Research Council. (2020). Reflecting from Youth-led initiatives in responding to the impact of Covid-19 on the agricultural value chain and associated socioeconomic activities. Human Sciences Research Council (HSRC) [Access: 18.07.2020]. Access on the internet: http://www.hsrc.ac.za/en/events/seminars/reflect-youth-led-initiative-respondingto-covid19

International Labour Organization (2020). DW4SD Resource Platform Theme: Informal Economy [Access: 16.07.2020]. Access on the internet: https://www.ilo.org/global/ topics/dw4sd/themes/informal-economy/lang--en/index.htm

Kiaga, A. (2020). Informal Economy: The impact of the COVID-19 on the informal economy in Africa and the related policy responses. International Labour Organization [Access: 20.07.2020]. Access on the internet: https://www.ilo.org/wcmsp5/groups/public/---africa/--ro-abidjan/documents/briefingnote/wcms_741864.pdf

Lazarte-Hoyle, A. (2017). Understanding the drivers of rural vulnerability. International Labour Organization [Access: 20.07.2020]. Access on the internet: https://www.ilo.org/wcmsp5/ groups/public/ed_emp/documents/publication/wcms_568736.pdf.

Loayza, N.V. (2016). Informality in the Process of Development and Growth. The World Bank.

Malemela, R.N., Yingi, L. (2016). The role of Local Economic Development in developing small medium enterprises: a case of Solomondale Community in the Limpopo Province. SAAPAM Limpopo Chapter 5th Annual Conference Proceedings.

Mapiye, M. (2016). Livelihoods after land reform resettlement programme: a critical appraisal of the Nyahukwe resettled farmers, Rusape, Zimbabwe. Master's thesis. University of the Western Cape [Access: 18.07.2020]. Access on the internet: http://etd.uwc.ac.za/ xmlui/bitstream/handle/11394/4931/Mapiye_m_ma_ems_2016.pdf?sequence $=1$

Marocchino C. (2009). A guide to upgrading rural agricultural retail markets. Agricultural management, marketing and finance working document, 24. Food and Agriculture Organization of the United Nations. Rome.

Mbatha, M.W., Nojiyeza, I.S., Mdiniso, J.M. (2021). Assessing the Sustainability of Agricultural Projects towards Improving Rural Livelihood in South Africa. "African Journal of Development Studies (formerly AFFRIKA Journal of Politics, Economics and Society)”, 2021(si1).

Mbonambi, G. (2020). Durban traders want fairness. Independent Online [Access: 20.07.2020]. Access on the internet: https://www.iol.co.za/business-report/companies/durban-traderswant-fairness- 1596348 
Ncube, B.L. (2017). Institutional support systems for small-scale farmers at new forest Irrigation Scheme in Mpumalanga, South Africa: constraints and opportunities. "South African Journal of Agricultural Extension”, 45(2).

Pafumi, M. (2020). Keeping the Food Value Chain Alive: Challenges and Solutions of Young Agripreneurs. Decent Jobs for Youth [Access: 18.07.2020]. Access on the internet: https://www.decentjobsforyouth.org/resource-details/Blogs/638

Petersen, E.K., Michelle, P., Pedersen, L. (2010). The Sustainable Livelihoods Approach: From a Psychological Perspective: Approaches to Development. Institute of Biology, University of Aarhus.

Ponsignon, F, Durrieu, F., Bouzdine-Chameeva, T. (2017). Customer experience design: a case study in the cultural sector. "Journal of Service Management".

Reardon, T., Timmer, C.P., Berdegué J.A. (2004). The rapid rise of supermarkets in developing countries: induced organizational, institutional, and technological change in agrifood systems. "eJADE: electronic Journal of Agricultural and Development Economics", 1(8532016-56108).

Rogan, M. (2018). Informal economies are diverse: South African policies need to recognise this. The conversation. [Access: 16.06.2020]. Access on the internet: https:// theconversation.com/informal-economies-are-diverse-south-african-policies-need-torecognise-this-104586

Serrat, O. (2008). The sustainable livelihoods approach (p. 5). Washington DC: Asia Development Bank.

(2017). The sustainable livelihoods approach [In:] Knowledge solutions (p. 21-26). Springer, Singapore.

Shaikh, H. (2020). Responding to the impacts of COVID-19 on informal workers in South Asia. International Growth Center [Access: 20.07.2020]. Access on the internet: https://www.theigc.org/blog/responding-to-the-impacts-of-covid-19-on-informal-workersin-south-asia/

The British Broadcasting Corporation (2020). Coronavirus: 'Under-25s and women financially worst-hit'. London: BBC New [Access: 19.07.2020]. Access on the internet: https://www.bbc.com/news/business-52176666

Tracey-White, J. (2003). Planning and designing rural markets. "Marketing Extension Guide (FAO)".

Trendov, N.M., Varas S., Zeng, M. (2019). Digital technologies in agriculture and rural areas. Briefing paper. Rome: Food and Agriculture Organization of the United Nations.

United States Agency for International Development (2018). Digital farmer profile: Reimagining Smallholder Agriculture. Washington D.C.: USAID.

DOI: $10.7862 /$ rz.2021.hss.32

The text was submitted to the editorial office: April 2021.

The text was accepted for publication: December 2021. 